\title{
Communicative system-activity approach in teaching english as a second language
}

\section{Zarnigor BAKHRIDDINOVA ${ }^{1}$, Gulmira JURABOYEVA ${ }^{2}$, Odina BAKHRIDDINOVA ${ }^{3}$ Otabek YUSUPOV 4}

Samarkand State Institute of Foreign Languages

\begin{tabular}{l} 
ARTICLE INFO \\
\hline Articlehistory: \\
Received April 2021 \\
Received in revised form \\
20 April 2021 \\
Accepted 15 May 2021 \\
Available online \\
25 June2021 \\
\hline Keywords: \\
language, \\
approach, \\
communicative system-activity, \\
content, \\
communication, \\
speech formation, \\
lexical aspects.
\end{tabular}

\begin{abstract}
This article outlines communicative system-activity approach in teaching English as a second language. This approach is the implementation of such a method of teaching, in which an orderly, systematic and mutually related teaching of the English language as a means of communication is carried out in the conditions of simulated (reproduced) speech activity in the classroom - an integral and integral part of the general (extralinguistic) activity. As a result of this approach in teaching, the system of English language proficiency as a means of communication in the broad sense of the word is formed, implemented and operates.
\end{abstract}

2181-1415/@ 2021 in Science LLC.

This is an open access article under the Attribution 4.0 International (CC BY 4.0) license (https://creativecommons.org/licenses/by/4.0/deed.ru)

\section{Ingliz tilini ikkinchi til sifatida o'qitish bo'yicha kommunikativ tizim- faollikyondashuvi}

\begin{tabular}{l}
\hline Kalitso'zlar: \\
Til, \\
yondashuv, \\
kommunikativ tizim faoliyati, \\
tarkib, \\
aloqa, \\
nutq shakllanishi, \\
leksikjihatlar.
\end{tabular}

\begin{abstract}
ANNOTATSIYA
Ushbu maqola ingliz tilini ikkinchi til sifatida o'qitish bo'yicha kommunikativ tizimlar bilan aloqa usuli haqida ma'lumot beradi. Ushbu yondashuv - bu ilg'or, muntazam va o'zaro bog'liq o'qitish usulini amalga oshirish, ularda sinfda simulyatsiya qilingan (qayta yaratish) nutq faoliyati davomida taqsimlangan (yaxlit) holatida amalga oshiriladi va umumiy (ekstraingualistik) faoliyatining ajralmas qismi hisoblanadi. Ta'lim sohasidagi ushbu yondashuv natijasida ingliz tilini bilish tizimi so'zning keng ma'noda muloqot vositasini shakllantiradi, amalga oshiradi va ishlab chiqadi.
\end{abstract}

\footnotetext{
${ }^{1}$ Student, Samarkand State Institute of Foreign Languages, Samarkand, Uzbekistan.

2 Student, Samarkand State Institute of Foreign Languages, Samarkand, Uzbekistan.

${ }^{3}$ Student, Samarkand State Institute of Foreign Languages, Samarkand, Uzbekistan.

${ }^{4}$ Phd, Samarkand State Institute of Foreign Languages, Samarkand, Uzbekistan.
} 


\section{Коммуникативно-системно-деятельностный подход в обучении английскому как второму языку}

\author{
Ключевые слова: \\ язык, \\ подход, \\ коммуникативная \\ система деятельности, \\ контент, \\ связь, \\ формирование речи, \\ лексические аспекты.
}

\begin{abstract}
АННОТАЦИЯ
Эта статья предоставляет информацию о методе связи с коммуникативными системами для преподавания английского языка как второй язык. Этот подход представляет собой реализацию прогрессивного, систематического и взаимосвязанного метода обучения, при котором имитационная (воссоздающая) речевая деятельность на занятиях осуществляется в распределенном (целостном) состоянии и является составной частью общей (внеязыковой) деятельности. В результате такого подхода в образовании система владения английским языком формирует, реализует и развивает средство общения в широком смысле слова.
\end{abstract}

Let us first consider in general terms the communicative system-activity approach to teaching English. The communicative system-activity approach assumes a complete and optimal systematization of the relationships between the components of the training content. These include the system of general (for example, extralinguistic, pedagogical) activity, the system of speech activity, the system of speech communication (communication, interaction and mutual perception), the system of the English language itself, the system of correlation of the native and English languages (their conscious comparative analysis), the system of speech mechanisms (speech generation, speech perception, speech interaction, etc.), the text as a system of speech products, the system of structural speech formations (dialogue, monologue, monologue in dialogue, different types of speech speech utterances and messages, etc. p.), the system (process) of mastering the English language, the system (structure) of human speech behavior. Such a system, taking into account its use for the purpose of teaching English, should also include the correlation of general activity motives with the motives and needs of communication related to it; the subject content and methods of performing activities; typical conditions of its course and the nature of the interaction of its participants (interindividual, group), as well as the definition of the nature, content and forms of relationships and communication of participants adopted within the framework of this activity: in the unity of their communicative, interactive and perceptual aspects, the role, place, spheres and situations of English-language speech communication.

The determining factors for teaching English are:

1) the nature of the impact of general activities on the content, selection and organization of educational language and speech material;

2) modeling of communication situations in the educational process and ways of forming speech skills and abilities of students;

3) methods and techniques of managing their educational activities in classes with a teacher and in independent work.

For educational purposes, the options of general activity are differentiated, provided that it is correlated with training: real (educational), actual (extracurricular) and potential (future).

Of great interest for creating a general activity basis for teaching English is the correlation of the units of activity: operations, actions and activities themselves. For the organization of management of the process of mastering the English language and the practice of English-language 
communication of students, the activity concept, including the theory of P.K. Anokhin about the acceptor of action, which justifies the interaction of the phases of planning, execution and comparison in the process of performing actions by a person, is of particular importance. In general, the systematization of general activity and the definition of its interaction with speech activity are carried out on the conceptual basis developed by L.S. Vygotsky, A.N. Leontiev, A.A. Leontiev and others.

\section{Speech activity}

Speech activity as a system is considered as an integral and integral part of the overall activity. Systematizing speech activity, it should be noted that for teaching English-language communication, both special and interrelated training in the types of speech activity that serve communication, including speaking, listening, reading and writing, is important. The hierarchy of units of speech activity (speech operation, speech action, and speech activity itself) provides the process of forming speech skills and abilities with order, systematicity, continuity, and consistency. The use of the theory of speech activity makes it possible to form the motives of English-language speech communication in the learning process and to ensure their implementation in the situations simulated in the classroom.

Systematization of communication involves the analysis of the content, structure and interaction of its communicative (information exchange between partners), interactive (interaction of partners) and perceptual (mutual perception and mutual understanding of partners) aspects. Of great interest for teaching English-language communication is the analysis of the combination of speech and non-speech means of communication (facial expressions, gestures, body movements, etc.) in the speech interaction of native speakers, taking into account their national and cultural specifics. Structural forms of communication (dialogue, monologue, monologue in dialogue, dialogue in monologue, polylogue), components of the act of communication (cycle, period, microdialog), speech genres of communication (monologuemessage, reasoning, proof, etc.), dialogue (conversation, dispute, question-and-answer dialogue, co - reflection, etc.), accepted in the English language speech etiquette and communication techniques in certain social situations, as well as the role repertoire of speech influences and reactions in the English language different situationally and thematically determined acts of communication.

\section{Systematization of language material}

The systematization of language material for teaching English communication involves the use of both the actual system description of the phonetic, lexical and grammatical aspects of the language, as well as data from communicative linguistics and pragmalinguistics, functional grammar, and contrastive linguistics. The systematization of language as a means of communication must meet three main requirements:

1) create a linguistic framework for teaching English, taking into account the language experience of students and their native language proficiency;

2) teach them a specific (full, truncated, or selective) version of the English language system;

3) meet the conditions for the implementation of the communicative function of the English language in teaching and mastering it by students.

In the process of selecting and organizing language and speech material and managing its mastery, the principle of evaluating their communicative expediency (V.G. Kostomarov) and the principle of active communication (A.A. Leontiev) should be used as the main ones. Along with teaching various units of the English language-phonetic, grammatical, lexical, intonation (prosodic) - functional utterances, various types of speech interaction of interlocutors, functional superphrasal unities, variants of speech implementation of communicative intentions (intentions) of interlocutors, variable methods of communicative response, speech communication techniques 
(including speech etiquette), samples of statements conditioned by role behavior, etc. become particularly important in teaching communication. The linguistic foundations of teaching Englishspeaking communication should combine the entire arsenal of language units and speech means of communication into a single whole.

The systematization of the correlation of the native language with English has three aspects:

1) selection and pre-school organization of language and speech material for teaching English-language communication;

2) dynamic correlation of language and speech units in the learning process;

3) formation of skills of correlation of native and English languages in the process of mastering the latter.

The training includes the linguistic and methodological typology of the studied language phenomena and the formation of skills and abilities of foreign language communication. Such a correlation requires the creation of special communicative reference books and textbooks that would allow students to develop the ability to quickly switch from one language to another and include an active comparison of the two languages in training, as well as to form a developed intermediary language in the linguistic thinking of students for the internal correlation of both languages in the process of generating and semantic perception of speech utterances in Englishlanguage communication, while maintaining the primacy of the native language in speech thinking. The correlation of the native and English languages in teaching English-language communication should be provided with such sets of exercises that, without compromising the authenticity of English-language speech, would allow the original communicative intentions to be fully realized by means of the English language (without adjusting them to the available language means) formed in speech thinking in the native language. In general, the creation of such sets of exercises is associated with the peculiarities of the structure and functioning of the mechanisms of generation and semantic perception of speech utterances that are part of the system that is appropriate for teaching English-language communication.

A methodically appropriate system of speech mechanisms creates a psychophysiological basis for speech communication. The most significant are the mechanisms of speech utterance generation, semantic perception, the mechanism of interaction between short-term and long-term memory, and the associated mechanism of probabilistic prediction in speech. Concepts of speech mechanisms proposed by T.V. Akhutina, N.I. Zhinkin, I.A. Zimnaya, A.A. Leontiev, A.R. Luria, and others, as well as the concept of the action acceptor P.K. Anokhina allow us to create a psycholinguistic model of the processes of mastering and mastering English (and any other foreign language) as a means of communication. The speech mechanisms formed on the material of the native language should not only be translated into a new (English-language) code, but also in the system of their functioning (taking into account the psychological reality of the native language), the interaction of the native and English languages should be debugged through the intermediary language, translation language, and analysis language formed in the process of learning and practicing English-language communication. At the same time, the intermediary language should be gradually curtailed and automated so that authentic speech functions in communication without visible delays in time.

\section{Text as a speech product system}

The text as a system of speech product of native speakers of the studied English language is of particular value as a systematized sample of the functioning of the language within the topic, context, situation, problem, sphere and genre of communication, orientation to a certain addressee, with a reflection of a certain social, activity background, expression of social, professional, personal 
position. The text is considered as a fixed product of oral or written speech in one form or another. In it, as it were, all other systems materialize. Taking into account the systems described above, it is possible to specifically model texts for educational purposes that would not only be models of English-language communication, but also would control the process of mastering and practicing English-language communication.

The text should be considered in the following teaching functions: as an illustration of the functioning of language units; as a sample of speech of a certain structure, form and genre; as a sample of the implementation of the author's speech intentions; as a model for generating speech utterances, messages or speech communication (text-dialogue); as a structure for managing semantic perception; as a structure for managing the educational actions of students (educational text) in teaching aspects of language (phonetics, vocabulary, grammar, intonation) and types of English-language speech activity (all types of reading, speaking, listening, writing). Dialogic texts, especially specially composed ones, can become the basis of independent communicative training, that is, self-learning in English-language communication. The functions of the text in teaching English-language communication are by no means limited to the above-mentioned ones. With the development of the communicative methodology, new functions may appear. The text as a system is closely related to structural speech formations - different types of texts of a monological and dialogical nature, mixed genres of utterances. Their systematization is necessary for teaching English-language communication in order to form students' ability to use various genres, tactics and techniques of speech communication, on the one hand, and their combination in accordance with the conditions of activity, the situation of communication, the nature of the role behavior of the interlocutors, their interpersonal and inter-role interaction, on the other. Training in different types of structural and speech formations should be provided, along with dictionaries and grammatical reference books, with special communicative textbooks. As experience shows, trainees often have difficulties in making a meaningful dialogue or a targeted monologue statement to a specific communication situation, conduct a multi-topic dialogue, or use various genres in their own detailed monologue statement (message, reasoning, proof, conclusion, narrative, description, assumption, etc.)

Systematization of English language acquisition involves taking into account and using in teaching objective and subjective patterns of English language acquisition based on the native language and its correlation with English. This systematization aims to bring together the psychological, psycholinguistic and linguistic features of mastering the English language and formulate a clear strategy and tactics for managing the learning activities of each student through a group (G.A. Kitaygorodskaya), which is, as the experience of intensive training shows, an indispensable condition for effective teaching of English-language communication. In the structure of mastering English-language communication, all the above-mentioned systems are implemented through the prism of the process of assimilation of knowledge, the formation of skills and abilities, provided that the general and socio - psychological, psycholinguistic mechanisms of speech activity and communication are used competently. The process of mastering English-language communication determines the system of managing the educational activities of students.

Systematization of speech behavior is important for teaching English-language communication in such aspects: as a reflection in it of all psychological, linguistic, activity, objective and subjective factors of its existence in the speech of a person as a whole; as a model or sample of speech behavior of a typical native English speaker, to which the learner should strive; as features of speech behavior as a result of training in English-language communication; as the formation of the ability of self-expression of the learner in English. 
The system of educational activities is consistent with the goals, nature and conditions of training and is determined by the peculiarities of mastering the English language as a means of communication. The main condition for improving and expanding the scope of educational activities for mastering English-language communication should be the complementary use of real (in the educational process), actual (extracurricular) and potential (planned) activities. An effective way to optimize learning activities can be game modeling, which is a recreation in the learning process based on the essential characteristics of the motives, goals, situations, conditions, process and results of the above-mentioned activities based on the use and organization of the students' gaming activities.

\section{CONCLUSION}

The experience of organizing English-language communication training in accordance with different methodological concepts shows that the lack of system-forming factors of such training significantly narrows the scope, degree and quality of using English as an effective means of communication. The most typical misconceptions in the methodology of teaching English-language communication are: substitution of the concept of speech communication with the concept of speech activity or the process of forming skills and abilities; specialization of teaching something to the detriment of another and the whole; taking the particular for the general and universal (for example, speech etiquette or the so-called "tourist" language is presented as communication or communication); identifying the oral reproduction of language material with communication; transferring communicative-inappropriate material into communication; mixing nomination with communication.

\section{REFERENCES:}

1. Belobragina J.I.B. Psychological features of students // Specialist. - 2000. - No. 3. - PP. 23-25.

2. Berman I.M. Methodology of English language teaching in non-linguistic universities. M.: Vysshaya SHKOLA. - 1970. - P. 231.

3. Boldyrev N.N. Linguistic bases of communicative methods of teaching a foreign language // Foreign languages at school. - M, 1988. Issue 3, 4 - P. 16-19.

4. Brushlinsky A.V. Subject: thinking, teaching, imagination. M., Publishing House "Institute of Practical Psychology"; Voronezh: "Modek", 1996. - P. 392.

5. Textbook on the methodology of teaching English: Reader in Methods of Teaching English / Comp. Gryzulina A.P. - M.: Prosveshchenie, 1983. - P. 159.

6. Chernova G.M. Lessons of communicative grammar: imperative mood in the French language. - 2000. - Issue Z. - P. 30-35.

7. Shales D. Communication skills in teaching modern languages. Strasbourg: Council of Europe Press, 1995. - P. 349.

8. Shtulman E.A. Fundamentals of experiment in the methodology of teaching foreign languages. Voronezh: VU, 1971. - P. 144.

9. Shubin E.P. Language communication and teaching foreign languages. Moscow: Prosveshchenie, 1972. - P. 350. 